\title{
Coronary artery distensibility is impaired in HIV patients without significant coronary atherosclerosis
}

\author{
Lia Petrose ${ }^{1 *}$, Micaela lantorno ${ }^{1}$, Sahar Soleimanifard ${ }^{1,2}$, Michael Schär $^{2}$, Richard Moore ${ }^{1}$, Gary Gerstenblith', \\ Robert Weiss ${ }^{1,2}$, Allison Hays $^{1}$
}

From 19th Annual SCMR Scientific Sessions

Los Angeles, CA, USA. 27-30 January 2016

\section{Background}

HIV infection is associated with an increased likelihood of coronary artery disease (CAD) and related events, but the underlying mechanisms are not well understood. Reduced coronary distensibility (CD) may contribute to the development of atherosclerosis and is present in CAD patients ${ }^{1}$. While aortic distensibility (AD) is known to be reduced in $\mathrm{HIV}^{2}$, CD in HIV patients has not been studied. We tested the hypothesis that $C D$ is reduced in HIV patients, even before the development of $C A D$, and that the reduction in $C D$ correlates with changes in $\mathrm{AD}$, reflecting diffuse changes in vascular material properties in HIV+ patients.

\section{Methods}

20 healthy adults and 13 HIV+ patients with a zero coronary artery calcium score on CT underwent 3T MRI to measure $C D$ and $A D$, as previously described to evaluate the relationship between $\mathrm{CD}$ and $\mathrm{AD}$. A subgroup of agematched healthy subjects $(\mathrm{N}=13$, age $=46.2 \pm 2.6 \mathrm{yrs}$, mean+/-SEM), were compared to the $13 \mathrm{HIV}+$ patients (from above, age $51.8 \pm 1.8$ yrs, $\mathrm{p}=0.1$ vs healthy) to compare $\mathrm{CD}$ and $\mathrm{AD}$ between groups. A proximal or mid segment of a major coronary artery and a cross section of the ascending aorta were imaged using cine spiral MRI for area measurements. Images were analyzed for crosssectional area during systole and diastole using semi-automated software (Cine vs3.15.17, General Electric), and distensibility $\left(\mathrm{mmHg}^{-1}\right)$ was determined: [(systolic lumen area-diastolic lumen area)]/(pulse pressure multiplied by diastolic lumen area $)^{3}$.

\section{Results}

$\mathrm{CD}$ was reduced in HIV+ patients, $\left(1.66 \pm 0.17 \mathrm{mmHg}^{-1}\right)$ as compared to that in healthy subjects $(2.43 \pm$ $0.21 \mathrm{mmHg}^{-1}, \mathrm{p}=0.008$, Fig 1A). Similarly, AD was decreased in HIV+ patients, $\left(1.49 \pm 0.20 \mathrm{mmHg}^{-1}\right)$ as compared to that in healthy subjects $\left(2.35 \pm 0.23 \mathrm{mmHg}^{-1}\right.$, $p=0.01$, Fig $1 B$ ). There was no significant difference in pulse pressure between the two groups. There was a significant positive relationship between $\mathrm{AD}$ and $\mathrm{CD}$ $(\mathrm{R}=0.50, \mathrm{p}=0.001$, Figure $1 \mathrm{C})$.

\section{Conclusions}

Coronary distensibility is reduced in HIV+ patients even before the development of detectable CAD and is similar in extent to the CD reduction reported in HIV-patients with known $C A D^{1}$. We confirm prior findings that $A D$ is reduced in HIV (with 0 Calcium score) and demonstrate for the first time a significant positive relationship between $A D$ and $C D$. The findings suggest that 1 ) vascular material properties are altered systemically in HIV+ patients even before CAD development and 2) a common mechanism of subclinical disease exists between the two vascular beds in HIV, possibly contributing to the increased risk for the development of atherosclerosis and cardiac events in HIV+ patients.

\section{Authors' details \\ ${ }^{1}$ Medicine, Johns Hopkins, Clarksville, MD, USA. ²Radiology, Johns Hopkins, Baltimore, MD, USA.}

Published: 27 January 2016

${ }^{1}$ Medicine, Johns Hopkins, Clarksville, MD, USA

Full list of author information is available at the end of the article 


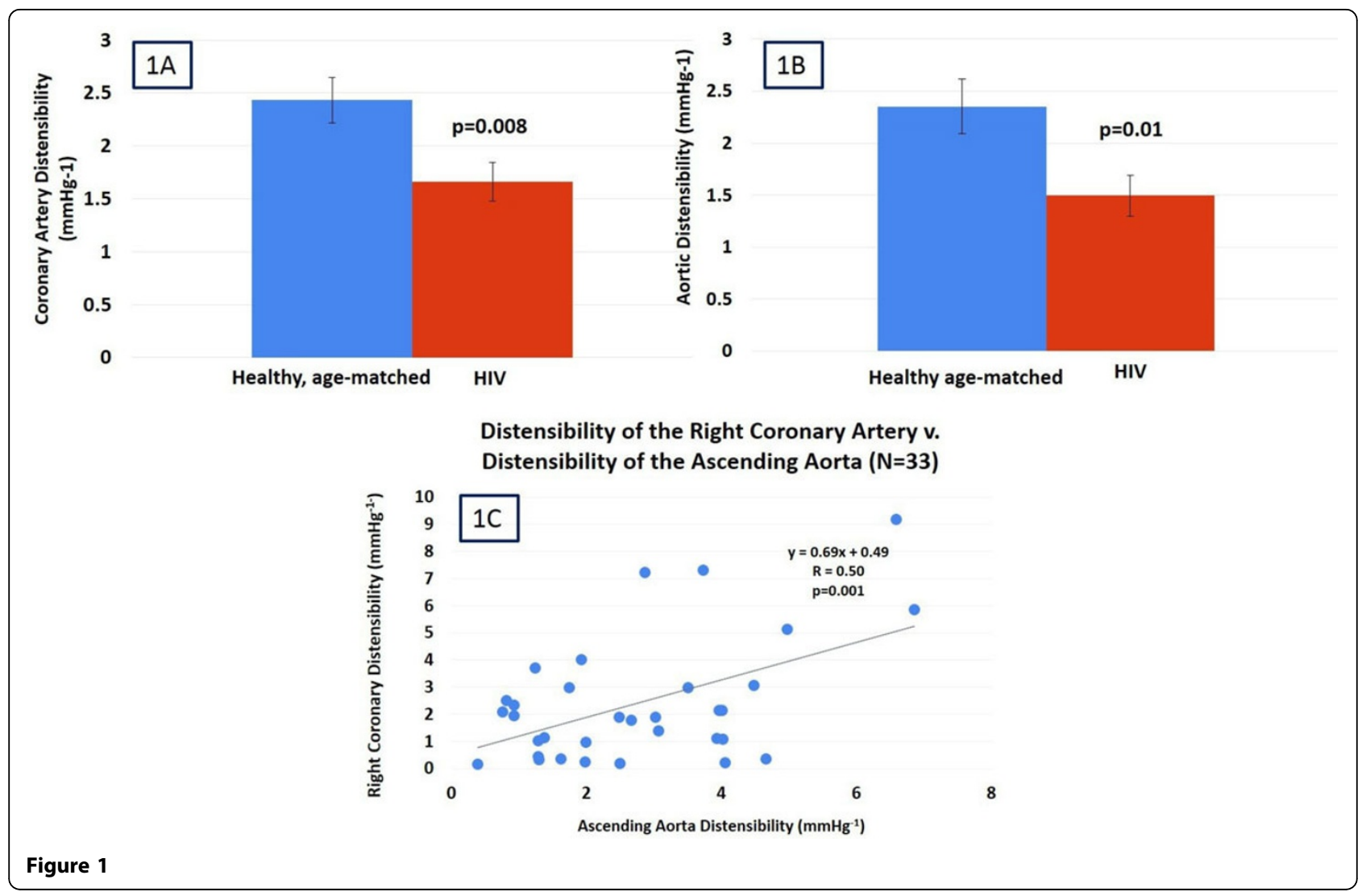

doi:10.1186/1532-429X-18-S1-053

Cite this article as: Petrose et al:: Coronary artery distensibility is

impaired in HIV patients without significant coronary atherosclerosis.

Journal of Cardiovascular Magnetic Resonance 2016 18(Suppl 1):O53.

Submit your next manuscript to BioMed Central and take full advantage of:

- Convenient online submission

- Thorough peer review

- No space constraints or color figure charges

- Immediate publication on acceptance

- Inclusion in PubMed, CAS, Scopus and Google Scholar

- Research which is freely available for redistribution

Submit your manuscript at www.biomedcentral.com/submit
C Biomed Central 